\title{
ANTIOXIDANT POTENTIAL, ANTITUMOR ACTIVITY AND PHENOLIC PROFILE OF PHOENIX DACTYLIFERA LINN
}

\author{
MANAL MORTADY HAMED ${ }^{*}$, MONA ABDEL MOTAGALLY MOHAMED ${ }^{1}$, WAFAA SABRY AHMED1,2 \\ ${ }^{1}$ Medicinal Chemistry Department, Theodor Bilharz Research Institute, Giza, Egypt, ${ }^{2}$ Department of Chemistry, College of Science and Arts, \\ Sajir, Shaqra University, Kingdom of Saudi Arabia \\ Email: manalayman90@yahoo.com
}

Received: 15 Jan 2017 Revised and Accepted: 31 Mar 2017

\begin{abstract}
Objective: Phoenix dactylifera Linn (Fam.: arecaceae) or date fruits are commercial crops that notarized in holy quran. $70 \%$ aqueous MeOH extract of the fruits led to isolation of six compounds; its chemical structures were determined as, $\beta$-sitosterol (1), caffeic acid (2), ferulic acid (3), protocatechuic acid (4), $p$-hydroxybenzoic acid (5) and luteolin (6).

Methods: The accurately weighed date fruits were washed, sliced and socked freshly in $70 \%$ methanol then exhaustively extracted under reflux for about $2 \mathrm{w}$ and filtered, then fractionated by different solvent; finaly the butanol extract evaporated and fractionated on a polyamide glass column. Using Sephadex LH-20 column to purify the compounds obtained. In our preliminary study, the extracts and compounds were subjected to in vitro cytotoxicity against HepG2 cell line through the MTT assay and the antioxidant potential of the extracts and pure compounds were assayed through in vitro model using (DPPH) and phosphomolybdenum assays.
\end{abstract}

Results: Compounds 2 and 3 exhibited promising antitumor activity with IC 50 values of 6 and $10 \mu \mathrm{g} / \mathrm{ml}$, respectively. Moreover compounds 1 , 4 , 5 and 6 showed cytotoxic activity with $\mathrm{IC}_{50}$ values of $13,15,21$ and $35 \mu \mathrm{g} / \mathrm{ml}$, respectively. The antioxidant potential of the compounds showed the inhibition percentage values $\left(\mathrm{SC}_{50}\right)$ ranged from 4.36 to $10.25 \mu \mathrm{g} / \mathrm{ml}$, while the total antioxidant capacity ranged from $(583.66$ to $702.00 \mathrm{mg}$ AAE/g compound).

Conclusion: Our study demonstrated that; dates constituents are powerful as antioxidant and antitumor; hence it is the best potential for pharmaceutical applications.

Keywords: Phenolics, Phoenix dactylifera, MTT assay, Extraction, Antioxidant

(C) 2017 The Authors. Published by Innovare Academic Sciences Pvt Ltd. This is an open access article under the CC BY license (http://creativecommons.org/licenses/by/4.0/) DOI: http://dx.doi.org/10.22159/ijpps.2017v9i5.18098

\section{INTRODUCTION}

Cancer is the second most regular reason for death around the world, according to the World Health Organization evaluations. Since the past time, medicinal plants are utilizing as a part of numerous natural reservation [1-4]. In addition, a considerable lot of the drugs sold for the treatment of tumor, are very costly, carcinogenic and mutagenic. Thus, there is a need to discover elective medications, which are profoundly powerful at non-harmful doses, economical and available to ordinary person. A need is in this way felt to look more up to date remedies, which are less expensive financially and don't have adverse effects [5]. Mainly, the existance of phenolic cancer prohibition factors is acknowledged to have the covering mechanisms thus these phenolic compounds have antioxidative properties that useful as cancer chemopreventive agents and at most inhibit carcinogenesis during the initiation phase, since they act as radical scavengers, for example, reactive oxygen species (ROS) [6-8]. Phoenix dactylifera, ordinarily known as date palm is belonging to palm family, arecaceae, edible plant used for sweet fruits and it is an important and one of the oldest trees cultivated by man [9]. Dates are the major fruit in Egypt, Saudi Arabia, and Middle Eastern countries. The species is generally developed and is naturalized in numerous tropical and subtropical areas around the world [10-12]. Some types of date fruits have promising effect in a few kinds of diseases and hepatotoxicity [13].

Cancer prevention phenolic compounds present in dates including flavonoids, ferulic, p-coumaric, sinapic acids, and procyanidins $[14,15]$.

Our study was planned to evaluate the phenolic profile, antitumor activity against HEPG2 cell line and antioxidant potential in different in vitro antioxidant assays including 1,1-diphenyl-2-picryl-hydrazyl (DPPH) free radical scavenging, Total antioxidant capacity and total phenolic contents of Phoenix dactylifera Linn fruits.

\section{MATERIALS AND METHODS}

Sample sources and collection

The date fruits were collected in Cairo, Egypt, during the winter season. This plant was taxonomically identified by Prof. Dr. Wafaa M. Amer, Professor of Plant Taxonomy, Faculty of Science, Cairo; University, Giza, Egypt; a voucher specimen (No. Ph. 1) was deposited at the herbarium of Medicinal Chemistry Department, Theodor Bilharz Research Institute, Giza, Egypt. The plant was washed and protected from light at $25^{\circ} \mathrm{C}$ until analysis.

General experimental procedure

Apparatus and chemicals required

${ }^{1} \mathrm{H}(300 \mathrm{MHz})$ and ${ }^{13} \mathrm{C}(75 \mathrm{MHz})$ NMR spectra were recorded on a JEOL GLM spectrometers, the chemical shifts were expressed in $\delta$ (ppm) with reference tetramethylsilane (TMS) as an internal standard in DMSO- $\mathrm{d}_{6}$ and coupling constant $(D)$ in Hertz. Mass spectra were recorded with an ESI-MS mass spectrometer in its negative mode, Finnigan TSQ 700 GC/MS coupled with a Finnigan electro spray source. IR spectra were recorded on PERKIN ELMER 1650 and on BRUKER vector 22 Germany apparatus. The melting points (m. p.) were determined using (SMDP3 Stuart Scientific UK) Melt-Apparatus. For antioxidant activity, the absorbance measurements were recorded using the UV-Vis spectrophotometer Spectronic 601 (Milton Roy, USA). The microplate reader (SunRise, TECAN, Inc, USA) was used to determine the percentage of viability and the number of viable cells. For column chromatography; cellulose C (Merck), sephadex LH 20 (Pharmacia, Uppsala, Sweden) and polyamide 6S (Riedel de Darmstadt, Germany) were used. For TLC pre-coated TLC plates and an aluminum sheet readymade were used within silica gel $60 \mathrm{~F}_{254}$ (Merck, Darmstadt, Germany). Whatman No. 1 sheets (Whatman International Ltd., Maidstone UK) 
were performed for paper chromatography (PC). The authentic samples were obtained from Medicinal Chemistry Laboratory [Biochemistry and Molecular Biology and Medicinal Chemistry Department, Theodor Bilharz Research Institute (TBRI), Cairo, Egypt]. The spots were observed by using UV radiation (254 and 366 $\mathrm{nm}$ ), and spraying with methanolic $\mathrm{FeCl}_{3}(1 \%), \mathrm{AlCl}_{3}(2 \%)$ and $10 \%$ $\mathrm{H}_{2} \mathrm{SO}_{4}$ followed by heating. The chemistry works were done at the Medicinal Chemistry Department, Theodor Bilharz Research Institute.

\section{Extraction procedure}

The accurately weighed date fruits $(3 \mathrm{~kg})$ were washed, sliced and socked freshly in $70 \%$ methanol ( $3 \times 5 \mathrm{l})$ then exhaustively extracted under reflux for about $2 \mathrm{w}$ and filtered. The filtrate was evaporated using rotary evaporator and the dark brown crude extract was kept in desiccators for using. The obtained dry residue, was defatted firstly with petroleum ether $\left(60-80{ }^{\circ} \mathrm{C}\right)(3 \times 2$ l) to give petroleum ether extract (44 g) and a residue, which was extracted with chloroform $(3 \mathrm{x}$ $2.5 \mathrm{l})$ to afforded, $(70 \mathrm{~g})$ chloroform extract and finally ethyl acetate (3 $\mathrm{x} 2 \mathrm{l})$ to obtain ethyl acetate extract (61 g) and a residue. The residue was partitioned between butanol and water; then the butanol extract evaporated to give $(200 \mathrm{~g})$ extract which was fractionated on a polyamide glass column $(110 \times 6 \mathrm{~cm}, 350 \mathrm{~g})$ using a stepwise gradient elution from $100 \% \mathrm{H}_{2} \mathrm{O}, \mathrm{H}_{2} \mathrm{O} / \mathrm{MeOH}$ mixtures up to $\mathrm{MeOH}$ pure. The obtained individual 110 fraction $(150 \mathrm{ml})$ each were collected into 5 fractions (A-E) according to $1 \% \mathrm{FeCl}_{3}$, Naturstoff spray reagents for detection and their chromatographic properties (Co-PC) with the use of UV light. Fraction $\mathrm{A}\left(\mathrm{H}_{2} \mathrm{O}, 20 \mathrm{~g}\right)$ totally has free sugar characters with disappearance of phenolic characters, and then was left behind. Fraction B (10\% methanol, $18 \mathrm{~g})$ was purified on a sephadex LH-20 column using $10 \%$ aqueous $\mathrm{MeOH}$ elution to afford a pure compound 1. Fraction C $(20-40 \% \mathrm{MeOH}, 23 \mathrm{~g})$, was chromatographed on sephadex LH-20 column for purification two times using $30 \%$ aqueous $\mathrm{MeOH}$ for elution, the first run afforded a pure compound 2 and the second rechromatograph using ( $n$-BuOH:2-propanol: $\mathrm{H}_{2} \mathrm{O}, \quad 4: 1: 5$, organic layer) (BIW) elution system, yeilded a pure compound 3 . Fraction D $(50-70 \% \mathrm{MeOH}, 23 \mathrm{~g})$, was fractionated on a cellulose column using $\mathrm{H}_{2} \mathrm{O} / \mathrm{MeOH}$ (7:3), resulted in fourteen subfractions, finally purified by successive fractionation on sephadex LH-20 CC using $\mathrm{H}_{2} \mathrm{O} / \mathrm{MeOH}(50 \%)$, resulted in chromatographically pure compounds 4, 5. Fraction E $(80-100 \% \mathrm{MeOH}, 21 \mathrm{~g})$ was rechromatographed three times on a sephadex LH-20 column using $\mathrm{H}_{2} \mathrm{O} / \mathrm{MeOH}(95 \%)$ eluent to afford pure compound 6. The isolation processes were carried out by using comparative PC using Whatman No. 1 paper and TLC plates with solvent systems (S1) $n$-BuOH: AcOH: $\mathrm{H}_{2} \mathrm{O}$ (4:1:5, upper layer) (PC), (S2) 15\% aqueous AcOH (PC), (S3) $\mathrm{CHCl}_{3}: \mathrm{MeOH}$ (9.5:0.5) (TLC), (S4) $\mathrm{CHCl}_{3}: \mathrm{MeOH}$ (8.5:1.5) (TLC), (S5) $\mathrm{CHCl}_{3}: \mathrm{MeOH}(7.5: 2.5)$ (TLC) and (S6) $\mathrm{CHCl}_{3}: \mathrm{MeOH}: \mathrm{H}_{2} \mathrm{O}$ (7:3:0.1) (TLC).

\section{Statistical analysis}

All data information was exhibited as mean \pm SD (standard deviation) for at least three separate results in triplicate for each trial point utilizing SPSS 13.0 program. Relation investigation of the antioxidant properties and free radical scavenging activities against the total phenolic contents of the plant extracts were done utilizing the relation by Microsoft Excel program.

\section{Free-radical scavenging assay (DPPH assay)}

The free-radical scavenging activity of the plant was measured as described before previously within some adaptations in which an electron-transfer that produces a violet solution in ethanol and it reduced in the presence of an antioxidant molecule, awarding led to a colorless ethanol solution [16]. Briefly, the reaction mixture composed of $2 \mathrm{ml}$ of $(100 \mu \mathrm{M})$ 1,1-diphenyl-2-picrylhydrazyl (DPPH) in ethanol added to $2 \mathrm{ml}$ of selected concentrations $(12-100 \mu \mathrm{g} / \mathrm{ml})$ of the extracts and compounds followed by incubation for $20 \mathrm{~min}$ in the dark, at room temperature. Absorbance of the mixture corresponding to the changes in color (from deep violet to light yellow) were read using a microplate spectrophotometer reader at $517 \mathrm{~nm}$ after $100 \mathrm{~min}$ of reaction. The mixture of ethanol and DPPH radical solution is (blank). The scavenging activity of DPPH was calculated as follows:

$$
\% \text { inhibition }=\left(A_{\text {blank }}-A_{\text {sample }} / A_{\text {blank }}\right) \times 100
$$

Where, Ablank is the absorbance of the control reaction mixture (DPPH solution appropriately diluted with ethanol) and $A_{\text {sample }}$ is the absorbance of the test extract or compound. $\mathrm{IC}_{50}$ (the sample concentration mediating $50 \%$ inhibition) was calculated from a graphic plot of inhibition percentage against sample concentration. The lower the $\mathrm{IC}_{50}$ value, the higher the antioxidant activity of the examined sample.

\section{Total antioxidant capacity assessment}

Total antioxidant capacity (TAC) of P. dactylifera Linn extracts and pure compounds was spectrophotometrically determined according to the phosphomolybdenum assay by using the method represented by Prieto et al., $[17,18]$. According to this method, $0.5 \mathrm{ml}$ of a 200 $\mu \mathrm{g} / \mathrm{ml}$ sample solution in methanol was mixed with $5 \mathrm{ml}$ phosphomolybdenum reagent solution $(28 \mathrm{mmol}$ sodium phosphate, $0.6 \mathrm{M}$ sulfuric acid and $4 \mathrm{mmol}$ ammonium molybdate) in dried test tubes. Incubation was then carried out to the reaction mixture for 90 min at $95{ }^{\circ} \mathrm{C}$ in water bath. After cooling the solutions at room temperature, their absorbances were measured using a spectrophotometer at $695 \mathrm{~nm}$ against a blank $(0.5 \mathrm{ml}$ methanol without the sample). Every test was accomplished in triplicate and the antioxidant activity of the samples was expressed as the number of equivalents of ascorbic acid (AAE) [18].

\section{Total phenolic assay}

The total phenolic content was determined by using the Folin-Ciocalteu assay for the plant extracts and pure compounds [19]. An aliquot (100 $\mu \mathrm{l})$ of sample $(100 \mu \mathrm{g} / \mathrm{ml})$ was added to $500 \mu \mathrm{l}$ of Folin-Ciocalteu phenol reagent and $1.5 \mathrm{ml}$ of $20 \% \mathrm{Na}_{2} \mathrm{CO}_{3}$ and shaken, the volume was then made up to $10 \mathrm{ml}$ of volumetric flask using distilled water. A blank was prepared using distilled water. Incubation to the reaction mixture for $120 \mathrm{~min}$ at room temperature, then the absorbance against the reagent blank was measured at $765 \mathrm{~nm}$ using an UV-Visible spectrophotometer. Total phenolic content was expressed as mg Gallic Acid Equivalents (GAE) per g extract/compound.

\section{Cytotoxicity analysis by MTT assay}

The cytotoxic effect of methanol and butanol extracts of Phoenix dactylifera Linn was evaluated by MTT assay using human liver cancer (HepG2) cell line. This MTT assay was outright by a slight modification of the strategy reported by Mosmann, 1983. The cells were grown as monolayers in growth RPMI-1640 medium supplemented with $10 \%$ inactivated fetal calf serum and $50 \mu \mathrm{g} / \mathrm{ml}$ gentamycin. The monolayers of 10.000 cells involved at the bottom of the wells in a 96-well microtiter plate incubated for $24 \mathrm{~h}$ at $37^{\circ} \mathrm{C}$ in a moisten incubator with $5 \% \mathrm{CO}_{2}$. The monolayers were then washed with sterile phosphate buffered saline and together the cells were handled with $100 \mu 1$ from different dilutions of the tested sample in fresh conservation medium and incubated at $37{ }^{\circ} \mathrm{C}$. A control of untreated cells was made in the lake of tested sample. A positive control containing doxroubcin drug was also tested as reference drug for differentiation. Six wells were used for each concentration of the tested sample. The observation under the inverted microscope was made Each $24 \mathrm{~h}$. The number of the surviving cells was determined under the inverted microscope. The number of the surviving cells was determined by smearing the cell lysing using 33\% glacial acetic acid and read the absorbance at 590 $\mathrm{nm}$ by using ELISA reader (SunRise, TECAN, Inc, USA) after wall blinding. $100 \%$ proliferation correspondence to the absorbance values from untreated cells. The number of viable cells was determined using ELISA reader as formerly (ODt/ODc) x $100 \%$ where ODt is the mean optical density of wells treated with the tested sample and ODc is the mean optical density of untreated cells. The $50 \%$ inhibitory concentration $\left(\mathrm{IC}_{50}\right)$, which is the concentration required to cause toxic effects in $50 \%$ of intact cells, was evaluated from graphic plots [20].

\section{RESULTS AND DISCUSSION}

\section{Compound 1 ( $\beta$-sitosterol)}

It is a white amorphous powder, m. p. $139{ }^{\circ} \mathrm{C}, \mathrm{R}_{\mathrm{f}}$ value 0.65 (S3), gave positive Liebermann and Salkowiski tests indicating its steroidal nature [21]. Its negative ESI-MS has a molecular ion peak at 
$\mathrm{m} / \mathrm{z} 413 .{ }^{1} \mathrm{HNMR}$ of 1 showed two singlet signals at $\delta 0.63$ and 0.95 assignable for methyl groups attached at C-18 and C-19, respectively. In addition three doublets were assigned at $\delta 0.85(d, J$ $=5.6 \mathrm{~Hz}), 0.81(d, J=4.9 \mathrm{~Hz})$ and $0.83(d, J=4.9 \mathrm{~Hz})$ for methyls attached at C-21, C-26 and C-27. Moreover, the methyl triplet at $\delta$ 0.77 assignable for $\mathrm{C}-29$. Also, a singlet signal at $\delta 5.30$ assigned for olifinic proton at $\mathrm{C}-6$. The ${ }^{13} \mathrm{C}$-NMR exhibeted 29 carbon signals for the $\beta$-sitosterol molecule, table (1). According to the above data compound 1 identified as $\beta$-sitosterol [22].

\section{Compounds 2 (caffeic acid) and 3 (ferulic acid)}

Compound 2 is yellowish white powder, m. p. $224{ }^{\circ} \mathrm{C}, \mathrm{R}_{\mathrm{f}}$ values 0.75 $\left(\mathrm{S}_{1}\right)$ and $0.50\left(\mathrm{~S}_{2}\right)$, gives blue color under long $U V$ light and compound 3 is creamy white powder, m. p. $170{ }^{\circ} \mathrm{C}, \mathrm{R}_{\mathrm{f}}$ values 0.72 $\left(\mathrm{S}_{1}\right)$ and $0.48\left(\mathrm{~S}_{2}\right)$, gives blue color under long UV light. Compounds 2 and 3 were expected to be cinnamic acid derivatives depending on their chromatographic characters and UV spectral data. Negative ESI-MS of 2 and 3 exhibited a molecular ion peak at $m / z 179$ and 193 [M-H] corresponding to a molecular formula of $\mathrm{C}_{9} \mathrm{H}_{8} \mathrm{O}_{4}$ and $\mathrm{C}_{10} \mathrm{H}_{10} \mathrm{O}_{4}$, respectively. In the ${ }^{1} \mathrm{HNMR}$ spectrum of the compounds 2 and 3 an AX-spin coupling system related to two $E$-olefinic protons were observed at $\delta 7.43,7.41(\mathrm{H}-7)$ and $6.25,6.24$ (H-8), respectively (each, $d, J=15.7 \mathrm{~Hz}$ ). Also, the ABM-system, at $\delta 6.86,6.85(d d), 7.04$, $6.95(d)$ and $6.74,6.27$ (each, $d, J=8.1 \mathrm{~Hz}$ ) of H-6, H-2 and H-5, respectively were confirming for a caffeoyl moiety in case of compound 2 and feruloyl moiety in case of compound 3 because of the presence of methoxy group signal at $\delta 3.74(3 \mathrm{H}, s)$. Representative 10 carbon signals of ferulic acid in case of 3 were appointed in its ${ }^{13} \mathrm{C}$-NMR spectra. The connection of the methoxy group at $\mathrm{C}-3$ was reasoned from the corresponding downfield signal of $\mathrm{C}-3$ at $\delta 148.62(\sim+\Delta 2 \mathrm{ppm})$, table (1) with respect to those of caffeic acid 2 ; consequantlly compounds 2 and 3 were identified as caffeic acid and ferulic acid [23].

\section{Compound 4 (protocatechuic acid)}

It is a gray crystalline powder, m. p. $221{ }^{\circ} \mathrm{C}, \mathrm{R}_{\mathrm{f}}$ value $0.49\left(\mathrm{~S}_{4}\right)$. It has a molecular ion peak at $\mathrm{m} / \mathrm{z} 153$ based on negative ESI-MS spectral data. The IR absorption band at $1677 \mathrm{Cm}^{-1}$ revealed the presence of carboxylic moiety. One spin coupling system was showed in the ${ }^{1}$ HNMR spectrum of 4 . The system was presented as a meta doublet at 7.44, a doublet of doublet at 7.25 and an ortho doublet of one proton at 6.78 which were refers to $\mathrm{H}-2 / 6$ and $\mathrm{H}-5$, respectively owing to $1,3,4$ tri-substituted benzene ring molecule. Based on the above discussed data, compound $\mathbf{4}$ was identified as protocatechuic acid [24].

\section{Compound 5 ( $p$-hydroxybenzoic acid)}

It is a white crystalline powder, m. p. $215^{\circ} \mathrm{C}, \mathrm{R}_{\mathrm{f}}$ value $0.43\left(\mathrm{~S}_{4}\right)$. From negative ESI-MS, it has a molecular ion peak at $\mathrm{m} / \mathrm{z} 137$. The IR absorption band at $1670 \mathrm{Cm}^{-1}$ indicating the presence of carboxylic group. ${ }^{1}$ HNMR spectrum showed one spin coupling system consists of two ortho doublets at 7.50 and 7.08 (each $d, J=7.5 \mathrm{~Hz}$ ) assigned to $\mathrm{H}-2,6$ and $\mathrm{H}-3,5$, respectively of 1 , 4-disubistituted benzene ring. Existence of p-substituted benzene ring was confirmed from ${ }^{13} \mathrm{C}$ NMR resonances at $132.01(\mathrm{C}-2,6)$ and $115.65(\mathrm{C}-3,5)$. The ${ }^{13} \mathrm{C}$ signal at 168.01 confirmed that compound 5 contains carboxylic group moiety. The ${ }^{13} \mathrm{C}$-signals at 121.89 and 162.20 were assigned for $\mathrm{C}-1$ and $\mathrm{C}-4$, respectively. Hence compound $\mathbf{5}$ was identified as $p$ hydroxybenzoic acid [25].

\section{Compound 6 (Luteolin)}

It is a yellow needle, m. p. $329^{\circ} \mathrm{C}, \mathrm{R}_{\mathrm{f}}$ values 0.43 (S5) and 0.59 (S6), gives dark purple color under long UV light. Based on its chromatographic characters, UV spectral data $\mathbf{6}$ was expected to be a luteolin-like structure. It has a molecular ion peak at m/z 285 from negative ESI-MS data. ${ }^{1}$ HNMR showed AMX spin coupling system of three aromatic protons at $7.57(d), 7.65(d d)$ and $6.89(d, J=8.7 \mathrm{~Hz})$ assigned for H-2', H-6' and H-5', respectively. Moreover, an AM spin coupling system consists of two doublets for H-6 and H-8 at $6.20(d, J$ $=2.1 \mathrm{~Hz})$ and $6.44(d, J=2.1 \mathrm{~Hz})$, respectively. As well as singlet signal assignable for $\mathrm{H}-3$ at 6.53. ${ }^{13} \mathrm{CNMR}$ spectra, table (1) revealed the presence of 15 carbon resonances, characteristic for a luteolin moiety. According to the above data, compound $\mathbf{6}$ was confirmed as luteolin [26].

Table 1: ${ }^{1} \mathrm{H}$ and ${ }^{13} \mathrm{C}-\mathrm{NMR}$ spectral data of compounds $1,2,3$ and 6 (300/75 MHz, DMSO-d6; TMS as internal standard)

\begin{tabular}{|c|c|c|c|c|c|c|c|c|}
\hline \multicolumn{2}{|c|}{ Compound 1} & \multicolumn{2}{|c|}{ Compound 2} & \multicolumn{2}{|c|}{ Compound 3} & \multicolumn{3}{|c|}{ Compound 6} \\
\hline C no. & ${ }^{3}$ CNMR & C no. & ${ }^{3}$ CNMR & C no. & ${ }^{3}$ CNMR & C no. & ${ }^{3}$ CNMR & 1HNMR \\
\hline 1 & 38.46 & 1 & 127.6 & 1 & 126.99 & 2 & 164.37 & \\
\hline 2 & 29.21 & 2 & 115.3 & 2 & 115.21 & 3 & 102.97 & $6.53 s$ \\
\hline 3 & 76.90 & 3 & 148.2 & 3 & 146.66 & 4 & 181.76 & \\
\hline 4 & 41.63 & 4 & 149.8 & 4 & 150.11 & 5 & 160.97 & \\
\hline 5 & 141.45 & 5 & 116.5 & 5 & 112.13 & 6 & 99.45 & $6.20 d$ \\
\hline 6 & 121.20 & 6 & 123.3 & 6 & 123.59 & 7 & 162.81 & \\
\hline 7 & 32.10 & 7 & 148.3 & 7 & 144.71 & 8 & 94.45 & $6.44 d$ \\
\hline 8 & 31.35 & 8 & 114.7 & 8 & 114.72 & 9 & 156.84 & \\
\hline 9 & 49.57 & 9 & 168.5 & 9 & 165.89 & 10 & 105.21 & \\
\hline 10 & 36.62 & & & $\mathrm{OCH}_{3}$ & 56.1 & $1^{\prime}$ & 121.13 & \\
\hline 11 & 20.61 & & & & & $2^{\prime}$ & 113.39 & $7.46 d$ \\
\hline 12 & 40.43 & & & & & 3 & 145.76 & \\
\hline 13 & 41.93 & & & & & $4^{\prime}$ & 149.95 & \\
\hline 14 & 56.29 & & & & & $5^{\prime}$ & 115.95 & $6.89 d$ \\
\hline 15 & 25.51 & & & & & $6^{\prime}$ & 119.01 & $7.56 d d$ \\
\hline 16 & 29.42 & & & & & & & \\
\hline 17 & 55.56 & & & & & & & \\
\hline 18 & 11.67 & & & & & & & \\
\hline 19 & 19.64 & & & & & & & \\
\hline 20 & 36.90 & & & & & & & \\
\hline 21 & 19.09 & & & & & & & \\
\hline 22 & 39.68 & & & & & & & \\
\hline 23 & 28.59 & & & & & & & \\
\hline 24 & 49.66 & & & & & & & \\
\hline 25 & 27.79 & & & & & & & \\
\hline 26 & 18.63 & & & & & & & \\
\hline 27 & 20.47 & & & & & & & \\
\hline 28 & 23.79 & & & & & & & \\
\hline 29 & 11.59 & & & & & & & \\
\hline
\end{tabular}

$\delta$ in ppm and $J$ in $\mathrm{Hz}$ 
<smiles>C=CCCC(CC)C(C)C</smiles>

1<smiles>COc1cc(/C=C/C(=O)O)ccc1O</smiles>

3<smiles>O=C(O)c1ccc(O)cc1</smiles>

5<smiles>O=C(O)/C=C/c1ccc(O)c(O)c1</smiles>

2<smiles>O=C(O)c1ccc(O)c(O)c1</smiles>

4<smiles>O=c1cc(-c2ccc(O)c(O)c2)oc2cc(O)c(O)cc12</smiles>

Fig. 1: Structure of compounds 1-6

\section{Free-radical scavenging antioxidant activity (DPPH assay)}

Cancer prevention agents or antioxidants are firmly identified with their biofunction, which is summarized for example, lowering the chronic diseases like carcinogenesis, mutagenesis, DNA harming [27]. Subsequently, antioxidant capacity is broadly utilized as a parameter for therapeutic bioactive molecules.

The phenolic compounds antioxidant activity is generally because of their redox properties, that can plays a promising role in absorbing and neutralizing the free radicals, or decomposing peroxides [28].

The antioxidant activity of $P$. dactylifera fruits was assessed by DPPH free radical method and ascorbic acid was used as standard $\left(\mathrm{SC}_{50}=\right.$ $7.97 \pm 1.34 \mu \mathrm{g} / \mathrm{ml}$ ) table (2). Our study shows the scavenging effect of the plant extracts on DPPH radical was in the following order butanol>methanol>ethyl acetate. In the present study, $n$-butanol extract was the most efficient for recovery of phenols; since at which the highest content of polyphenols was observed, its $\mathrm{SC}_{50}$ value was $17.63 \pm 0.38$. The $\mathrm{SC}_{50}$ values for free radical scavenging activity among the plant extracts were observed to be; $29.60 \pm 1.03$, $38.19 \pm 1.51$ and $31.45 \pm 1.29 \mu \mathrm{g} / \mathrm{ml}$ for the fresh date's methanolic, dried dates methanolic and ethyl acetate extracts, respectively. So $n$ butanol extract proved to be the most effective solvent for isolation of phenolic compounds. Ideal structure for the scavenging of free radicals since structure of these molecules incorporates various hydroxyls acting as hydrogen donors which make them very powerful antioxidant factor. Caffeic acid represents the maximum scavenging activity between the samples studied with $\mathrm{Sc}_{50}$ value of $4.36 \pm 2.10 \mu \mathrm{g} / \mathrm{ml}$, followed by ferulic acid with $\mathrm{Sc}_{50}$ value of $5.12 \pm 1.10 \mu \mathrm{g} / \mathrm{ml}$; while compounds $1,4,5$ and 6 was found to be have $\mathrm{Sc}_{50}$ value of $10.25 \pm 1.35,6.63 \pm 0.48,7.65 \pm 0.39$ and $8.50 \pm 2.11$ $\mu \mathrm{g} / \mathrm{ml}$, respectively, table (2). Our study showed that, a significant positive correlation between the antioxidant activity and phenolic compounds. These findings agreed with Saleh et al., (2011) who notify that date fruits can be viewed a rich of hydrophilic antioxidants and this reducing power is generally correlated with the existence of polyphenols [28]. Recently the research serves; caffeic acid was always behaves as potent antioxidant compared with ferulic acid, in inhibiting LDL oxidation and quenching radicals [28-30]. Thus, antioxidant compounds might influence on malignancy cells by giving high intensity of oxygen by acting with its radicals shape and thus aggravates tumor hypoxia required for these cells and also causes apoptosis [31-33]. Our study presents that, the total antioxidant capacity of $P$. dactylifera Linn ranged from (298.66 $\mathrm{mg} \mathrm{AAE} / \mathrm{g}$ compound) to (702.00 mg AAE/g compound), table (2).

\section{Total phenolic contents assay}

The total phenolic contents of $P$. dactylifera Linn extracts decreased in the order $n$-BuOH $>\mathrm{MeOH}>$ EtOAc, these results also, agreed with the results concluded from the DPPH free radical assay which revealed that, $n$-BuOH extract indicated high total antioxidant capacity when compared with the other extracts of the plant which might be because of the presences of high percentages of phenolic compounds. As shown from results in table (2) the highest product of total phenolic content was found to be in $n$ - $\mathrm{BuOH}$ extract (533.92 mg gallic acid equivalent/g extract), followed by EtOAc extract (299.05 mg gallic acid equivalent/g extract), $\mathrm{MeOH}$ fresh dates extract (253.06 mg gallic acid equivalent/g extract), and $\mathrm{MeOH}$ dried dates extract (206.21 mg gallic acid equivalent/g extract), table (2). From our point of view it has been appeared that, the higher contents of total phenolics in P. dactylifera Linn may be contributed by presence of caffeic acid, ferulic acid, protocateuic acid, $p$ hydroxybenzoic acid and luteolin which are represents a promising antioxidant activity. 
Table 2: Free radical scavenging potential (DPPH) and total antioxidant capacity (TAC) of the extracts and isolated pure compounds from Phoenix dactylifera Linn

\begin{tabular}{llll}
\hline Sample & aDPPH SC $\mathbf{5 0}(\boldsymbol{\mu g} / \mathbf{m l})$ & $\begin{array}{l}\text { bTotal antioxidant capacity } \\
\text { (mg AAE/g sample) }\end{array}$ & $\begin{array}{l}\text { cTotal phenolic content) } \\
\text { (mg GAE/g ext.) }\end{array}$ \\
\hline Methanol ext. fresh dates & $29.60 \pm 1.03$ & $362.00 \pm 2.00$ & $253.06 \pm 1.85$ \\
Methanol ext. dried dates & $38.19 \pm 1.51$ & $298.66 \pm 2.30$ & $206.21 \pm 1.56$ \\
Ethyl acetate ext. & $31.45 \pm 1.29$ & $335.33 \pm 3.05$ & $299.05 \pm 2.67$ \\
Butanol ext. & $17.63 \pm 0.38$ & $464.00 \pm 2.00$ & $533.92 \pm 1.18$ \\
Compd. 1 & $10.25 \pm 1.35$ & $583.66 \pm 0.57$ & \\
Compd. 2 & $4.36 \pm 2.10$ & $702.00 \pm 2.00$ & \\
Compd. 3 & $5.12 \pm 1.10$ & $692.66 \pm 2.08$ & \\
Compd. 4 & $6.63 \pm 0.48$ & $600.33 \pm 1.52$ & \\
Compd. 5 & $7.65 \pm 0.39$ & $592.33 \pm 1.52$ & \\
Compd. 6 & $8.50 \pm 2.11$ & $584.66 \pm 1.15$ & \\
\hline
\end{tabular}

Data are expressed as mean \pm standard deviation $(\mathrm{n}=3)$, aDPPH results are expressed as $\mu \mathrm{g}$ compound $/ \mathrm{ml}(\mu \mathrm{g} / \mathrm{ml})$, bTotal antioxidant capacity results are expressed as mg ascorbic acidquivalent/g extract (mg AAE/g compound), cTotal phenolic content are expressed as mg gallic acid equivalent (mg GAE/g ext.)

Mexican and Chinese studies concluded that, betasitosterol dose-dependently reduced the level of free radicals by the scavenging of ROS and causes conservation of mitochondrial membrane constancy and increased antioxidant enzymes [3437]. Protocatechuic acid was showed to have several pharmacological impacts which might be firmly agreed with its antioxidant activities [38-41]. It was noticed that the radical scavenging activity assay and total antioxidant capacity assay of the extracts was strong directly positive correlated with their total phenolic contents (Correlation coefficients; $\mathrm{R}^{2}=0.912$ and 0.909 , respectively), fig. $(2,3)$. This is in agreement with other studies in the literature which present positive correlations between the quantity of phenolic compounds in the extract and the DPPH free radical scavenging activity [42].

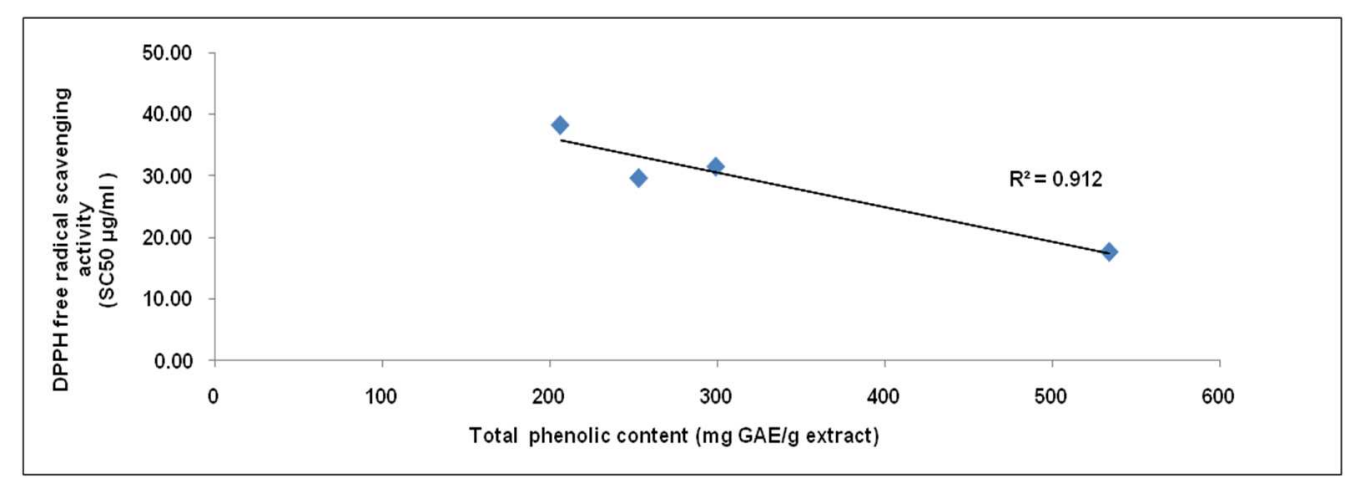

Fig. 2: Correlation between the DPPH radical scavenging activities of different extracts of $P$. dactylifera Linn and their total phenolic contents

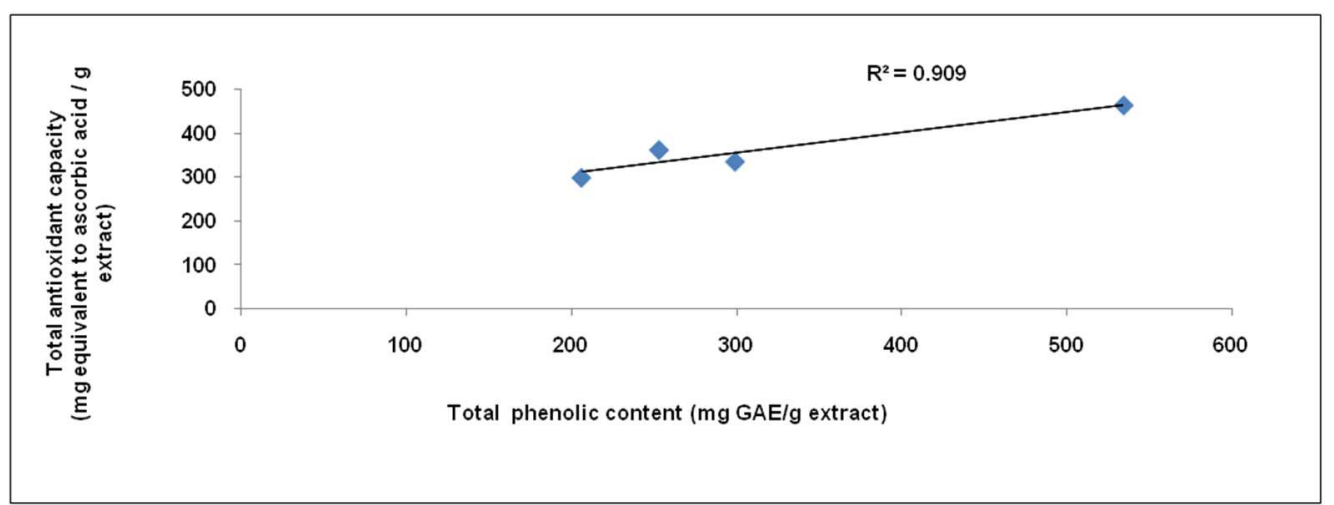

Fig. 3: Correlation between the total antioxidant capacity of the different extracts of $P$. dactylifera Linn and their total phenolic contents

\section{Cytotoxic activity}

MTT assay is a fast with high precision colorimetric approach that generally used to decide cell growth and cell cytotoxicity, especially in the improvement of new medication. A sample is generally considered to have in vitro cytotoxic activity if the $\mathrm{IC}_{50}$ value (concentration that causes a $50 \%$ cell kill) in carcinoma cells, is less than $20 \mathrm{~g} / \mathrm{ml}$ [43]. Our study demonstrated a strong in vitro toxicity towards HepG2 cell lines obtained from methanol, ethyl acetate, and butanol extracts within the pure compounds. Butanol extract being more active than the other extracts within a high inhibitory effect with $\mathrm{IC}_{50}$ value of $18 \mu \mathrm{g} / \mathrm{ml}$, while methanol and ethyl acetate 
extracts showed moderate effect with $\mathrm{IC}_{50}$ values of 34 and 35 $\mu \mathrm{g} / \mathrm{ml}$, respectively following $24 \mathrm{~h}$ treatment, fig. (4). Due to the active constituents of the butanol extract guided us to some isolation of valuable compounds that have the ability to damaged carcinoma cells. Therefore compounds 2 and 3 exhibited pronounced cytotoxicity against HepG2 cell lines with $\mathrm{IC}_{50}$ values of 6 and 10 $\mu \mathrm{g} / \mathrm{ml}$, respectively, fig. (5). Furthermore, compounds 1, 4, 5 and 6 showed cytotoxic activity with $\mathrm{IC}_{50}$ values of $13,15,21$ and 35 $\mu \mathrm{g} / \mathrm{ml}$, respectively against liver carcinoma cell lines.

Protocatechuic acid (PCA) is generally dispersed and introduce in most edible plants utilized in folk medicine [44], additionally it shows an anticarcinogenic effectiveness in liver and encourage apoptosis in human leukemia cells $[45,46]$.

luteolin, 4-hydroxybenzoic acid and protocateuic acid as minor constituents showed greatest hepatoprotective activity [47]. $\beta$ sitosterol furthermore, exhibited antiproliferative and apoptosis activities in human leukemic U937 and prostate cancer cells [48, 49]. Ethyl protocatechuate was established to neutralize the $\mathrm{H}_{2} \mathrm{O}_{2}$ motivate cytotoxicity in Chinese hamster v79 cells [50].
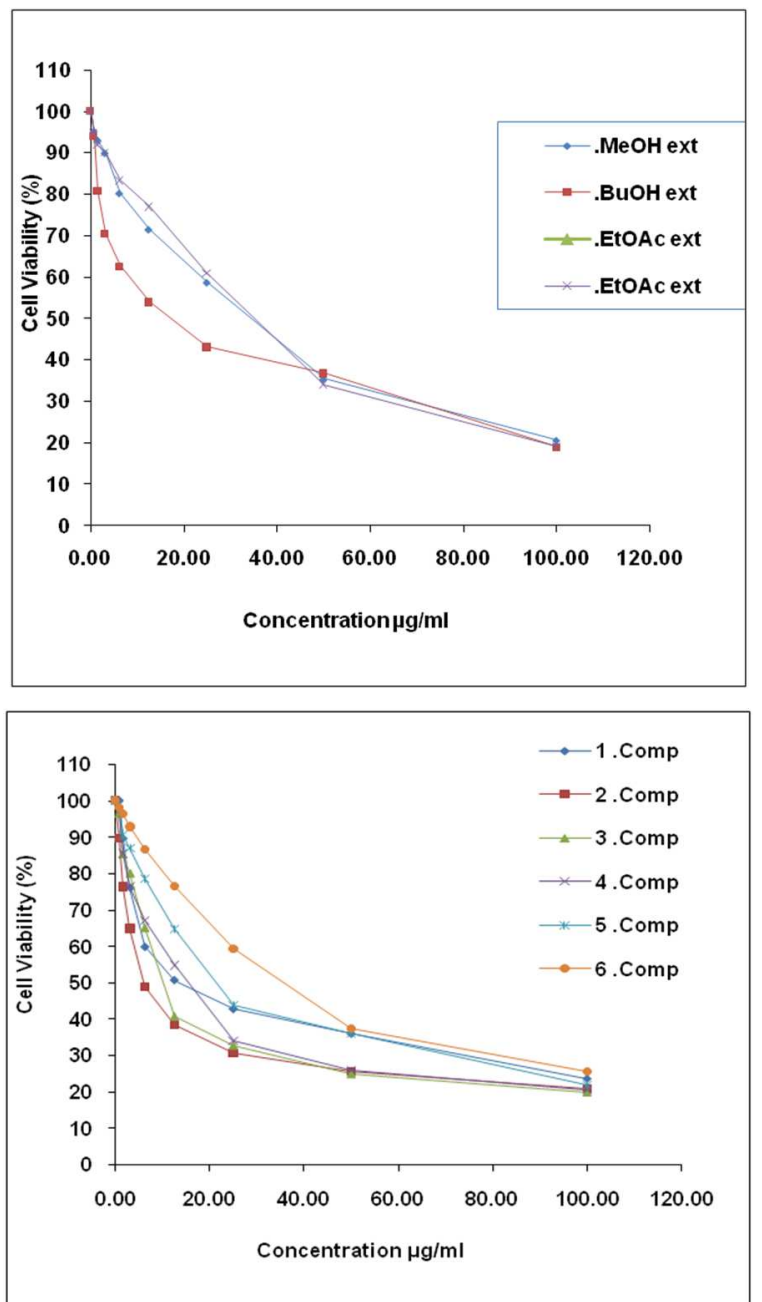

Fig. 4. Effect of methanol, ethyl acetate and fig. 5. Effect of compounds 1-6 against butanol extracts of $P$. dactylifera Linn liver tumor HepG2 cell line against liver tumor HepG2 cell line

\section{Structure activity relationship}

The presence of- $\mathrm{CH}=\mathrm{C}-\mathrm{COOH}$ groups in caffeic and ferulic acids guarantees greater $\mathrm{H}$-donating capability and consequent radical stability than the carboxylic group in $p$-hydroxybenzoic acids. The reduced potentials of radicals resulted from benzoic acid and 3,4- dihydroxybenzoate decrease with the electron donating power at $\mathrm{C} 1$. Along these lines, caffeic and ferulic acids were found to be more active than protocatechuic and p-hydroxybenzoic acids [51]. Since the phenolic profile of date fruits is predominantly depends on caffeic and ferulic acids; so this potential antioxidant activity was normally expected. At last, this phenolic profile present a right tool to rationalize the geographic source of date fruits activities.

\section{CONCLUSION}

The present study revealed the phenolic and cytotoxic spectrum of medicinally date fruits. Moreover the high contents of phenolic compounds specified that these compounds contribute to the antioxidant activity profile, so Phoenix dactylifera Linn can be regarded as promising natural plant sources of antioxidants. Our study conducted the presence of different phytochemicals such as phenolic compounds and sterols; they are $\beta$-sitosterol (1), caffeic acid (2), ferulic acid (3), protocatechuic acid (4), $p$-hydroxybenzoic acid (5) and luteolin (6). In vitro antioxidant activity revealed that, the most efficient extraction medium for phenolic compounds was butanol extract followed by methanol extract which showed moderate phenolic contents and ethyl acetate extract which showed the lowest content of phenolic compounds. Caffeic acid exhibited a potent cytotoxic activity among the tested compounds against liver carcinoma HepG2 cell line. The present review demonstrated that; the Egyptian date fruits include a great percentage of phenolic metabolites with high level of antioxidant potential which support its uses as a utilitarian food. Therefore this report may be serving as a footstep regarding the biological and pharmacological activities of a natural plant source Phoenix dactylifera Linn fruits and sustain their use in healthcare.

\section{CONFLICT OF INTERESTS}

Declared none

\section{REFERENCES}

1. Hamed MM. Volatile oils from Pelargonium zonale and its cytotoxic effect on tumor cells. Bull Fac Pharm Cairo Univ 2007;45:297-300.

2. Hamed M, Mohamed M, Refai L, Hammam O, El-Ahwany E, Salah F, et al. The active constituents of Pelargonium zonale induced cytotoxicity in human hepatoma cell line HepG2. Int J Pharm Appl 2015;6:10-9.

3. Hamed MM, Mohamed MA, Ibrahim MT. Cytotoxic activity assesment of secondary metabolites from Tecomaria capensis v. aurea. Int J Pharmacogn Phytochem Res 2016;8:1173-82.

4. Hassanein H, El-Ahwany E, Salah F, Hammam O, Refai L, Hamed M. Extracts of five medicinal herbs induced cytotoxicity in both hepatoma and myloma cell lines. Cancer Sci Ther 2010;3:239-43.

5. Yue-Zhong S. Recent natural products based drug development: a pharmaceutical industry perspetive. J Nat Prod 1998;61:1053-71.

6. Hamed MM, Mohamed MA, Ibrahim MT. Phytochemical investigation and cytotoxic characterization of bioactive constituents from Conyza dioscoridis. Int J Pharmacogn Phytochem Res 2015;7:948-55.

7. Ho CT. Phenolic compounds in food: an overview. In: Huang MT, Ho CT, Lee CY. Eds. Phenolic Compounds in Food and Their Effects on Health II: Antioxidants and Cancer Prevention, American Chemical Society Symposium Series 507. Am Chem Soc, Washington, DC; 1992. p. 2-7.

8. Ito N, Hirose M. Antioxidants-carcinogenic and chemopreventive properties. Adv Cancer Res 1989;53:247-302.

9. Beech. Archaeobotanical evidence for early date consumption in the Arabian Gulf: The Date Palm, Abu Dhabi, UAE: The Emirates Center for Strategic Studies and Research; 2003. p. 11-32.

10. Kew World Checklist of Selected Plant Families, Phoenix dactylifera; 1753. p. 1188

11. Biota of North America Project, Phoenix dactylifera; 2015.

12. Flora of China. Phoenix dactylifera; 1753. p. 143.

13. Abdu SB. The protective role of Ajwa date against the hepatotoxicity induced by Ochratoxin A. Egypt J Nat Tox 2011;8:1-15. 
14. Mansouri A, Embarek G, Kokkalou E, Kefalas P. Phenolic profile and antioxidant activity of the Algerian ripe date palm fruit (Phoenix dactylifera). Food Chem 2005;89:411-20.

15. Gu L, Kelm MA, Hammerstone JF, Beecher G, Holden J, Haytowitz D, et al. Screening of foods containing proanthocyanidins and their structural characterization using LC-MS/MS and thiolytic degradation. J Agric Food Chem 2003;51:7513-21.

16. Marwah RG, Fatope MO, Mahrooqi RA, Varma GB, Abadi HA, AlBurtamani SKS. Antioxidant capacity of some edible and wound healing plants in Oman. Food Chem 2007;101:465-70.

17. Prieto P, Pineda M, Aguilar M. Spectrophotometric quantitation of antioxidant capacity through the formation of a phosphomolybdenum complex: specific application to the determination of Vitamin E1. Anal Biochem 1999;269:337-41.

18. Hamed MM, Refahy LA, Abdel-Aziz MS. Assessing the bioactivity and antioxidative properties of some compounds isolated from Abutilon hirtum (lam.). Asian J Pharm Clin Res 2017; 10:333-40.

19. Kumar KS, Ganesan K, Rao PV. Antioxidant potential of solvent extracts of Kappaphycus alverezii (Doty). Edible seaweed. Food Chem 2008;107:289-95.

20. Mosmann T. Rapid colorimetric assay for cellular growth and survival: application to proliferation and cytotoxicity assays. J Immunol Methods 1983;65:55-63.

21. Shmidt J. "Organic Chemistry" Oliver and Bayed, Edinburgh and London. $8^{\text {th }}$ Ed; 1964. p. 318-673.

22. Paul SB, Singha S. Isolation and identification of physiologically important sterols and sterol glycosides from Basella rubra linn. Biol Environ Sci 2010;5:120-2.

23. Lu Y, Foo LY. Polyphenolics of salvia-a review. Phytochemistry 2002;59:114-7.

24. Al-Musayeib N, Perveen S, Fatima I, Nasir M, Hussain A. Antioxidant, anti-glycation and anti-inflammatory activities of phenolic constituents from Cordia sinensis. Molecules 2011;16:10214-6

25. Pandey DP, Rather MA, Nautiyal DP, Bachheti RK. Phytochemical analysis of Abutilon indicum. Int J Chem Tech Res 2011;3:642-5.

26. Harborne JB, Mabry TJ, Mabry H. The flavonoids. Chapman and Hall, London; 1975.

27. Zhu QY, Hackman RM, Ensunsa JL, Holt RR, Keen CL. Antioxidative activities of oolong tea. J Agric Food Chem 2002;50:6929-34.

28. Osawa T. Novel natural antioxidants for utilization in food and biological systems. In Uritani I, Garcia VV, Mendoza EM. Eds. Post harvest biochemistry of plant food-materials in the tropics. Japan Scientific Societies Press, Japan; 1994. p. 241-51.

29. Saleh EA, Tawfik MS, Abu-Tarboush HM. Phenolic contents and antioxidant activity of various date palm (Phoenix dactylifera L.) Fruits from Saudi Arabia. Food Nutr Sci 2011;2:1134-41.

30. Meyer AS, Donovan JL, Pearson DA, Waterhouse AL, Frankel EN. Fruit hydroxycinnamic acids inhibit low density lipoprotein oxidation in vitro. J Agric Food Chem 1998;46:1783-7.

31. Cartron E, Carbonneau MA, Fouret G, Descomps B, Leger CL. Specific antioxidant activity of caffeoyl derivatives and other natural phenolic compounds: LDL protection against oxidation and decrease in the proinflammatory lysophosphatidylcholine production. J Nat Prod 2001;64:480-6.

32. Kikuzaki H, Hisamoto M, Hirose K, Akiyama K, Taniguchi H. Antioxidant properties of ferulic acid and its related compounds. J Agric Food Chem 2002;50:2161-8.

33. Van der Burg B. Sex steroids and growth factors in mammary cancer. Acta Endocrinol (Copenh) 1991;125:38-41.
34. Dev S. Impact of natural products in modern drug development. Indian J Exp Biol 2000;48:191-8.

35. Haroon AM. Effect of some macrophytes extracts on growth of Aspergillus parasiticus. Egypt J Aquatic Res 2006;32:301-13.

36. Paniagua-Pérez R, Madrigal-Bujaidar E, Reyes-Cadena S, Alvarez-González I, Sánchez-Chapul L, Pérez-Gallaga J, et al. "Cell protection induced by beta-sitosterol: inhibition of genotoxic damage, stimulation of lymphocyte production, and determination of its antioxidant capacity. Arch Toxicol; 2008. p. 6.

37. Li CR, Zhou Z, Lin RX, Zhu D, Sun YN, Tian LL, et al. betasitosterol decreases irradiation-induced thymocyte early damage by regulation of the intracellular redox balance and maintenance of mitochondrial membrane stability. J Cell Biochem 2007;102:748-58.

38. Shi GF, An LJ, Jiang B, Guan S, Bao YM. Alpinia protocatechuic acid protects against oxidative damage in vitro and reduces oxidative stress in vivo. Neurosci Lett 2006;403:206-10.

39. Tanaka T, Tanaka T, Tanaka M. Potential cancer chemopreventive activity of protocatechuic acid. J Exp Clin Med 2011;3:27-33.

40. Lin CY, Huang CS, Huang CY, Yin MC. Anticoagulatory, antiinflammatory and antioxidative effects of protocatechuic acid in diabetic mice. J Agric Food Chem 2009;57: 6661-7.

41. Lee MJ, Chou FP, Tseng TH, Hsieh MH, Lin MC, Wang CJ. Hibiscus protocatechuic acid or esculetin can inhibit oxidative LDL induced by either copper ion or nitric oxide donor. J Agric Food Chem 2002;50:2130-6.

42. Sagar BK, Singh RP. Genesis and development of DPPH method of antioxidant assay. J Food Sci Technol 2011;48:412-22.

43. Lee CC, Houghton P. Cytotoxicity of plants from Malaysia and Thailand used traditionally to treat cancer. J Ethnopharmacol 2005;100:237-43.

44. Liu RH. Potential synergy of phytochemicals in cancer prevention: mechanism of action. J Nutr 2004;134:3479S-85S.

45. Tanaka T, Kojima T, Kawamori T, Mori H. Chemoprevention of digestive organs carcinogenesis by natural product protocatechuic acid. Cancer 1995;75:1433-9.

46. Tseng TH, Hsu JD, Lo MH, Chu CY, Chou FP, Huang CL, et al. Inhibitory effect of hibiscus protocatechuic acid on tumor promotion in mouse skin. Cancer Lett 1998;126:199-207.

47. Hui Mei L, Hsien Chun T, Chau Jong W, Jin-Jin L, Chia Wen L, Fen-Pi C. Hepatoprotective effects of cassia fistula. Linn extract against $\mathrm{CCl}_{4}$ induced oxidative damage in rats. Chem Biol Interact 2008;171:283-93.

48. Park C, Moon DO, Rhu CH, Choi BT, Lee WH, Kim GY, et al. $\beta$ sitosterol induces antiproliferation and apoptosis in human leukemic U937 cells through activation of caspase-3 and induction of Bax/Bcl-2 ratio. Biol Pharm Bull 2007;30:1317-23.

49. Holtz RL, Fink CS, Awad AB. Beta-sitosterol activates the sphingomyelin cycle and induces apoptosis in LNCaP human prostate cancer cells. Nutr Cancer 1998;32:8-12.

50. Nakayama M, Nagata K, Ishihama A. Enzymatic properties of the mouse Mxl protein-associated GTPase. Virus Res 1992;22:227-34.

51. Cuvelier ME, Richard H, Bercet C. Comparison of the antioxidant activity of some acid-phenols: Structure-activity relationships. Biosci Biotechnol Biochem 1992;56:324-5.

\section{How to cite this article}

- Manal Mortady hamed, Mona Abdel Motagally Mohamed, Wafaa Sabry Ahmed. Antioxidant potential, antitumor activity and phenolic profile of Phoenix dactylifera linn. Int J Pharm Pharm Sci 2017;9(5):130-136. 